\title{
Article
}

\section{The Secretome of Human Neonatal Mesenchymal Stem Cells Modulates Doxorubicin-Induced Cytotoxicity: Impact in Non-Tumor Cells}

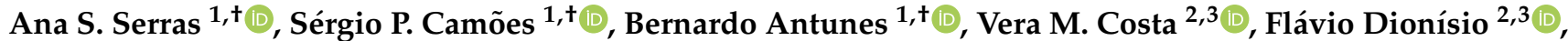

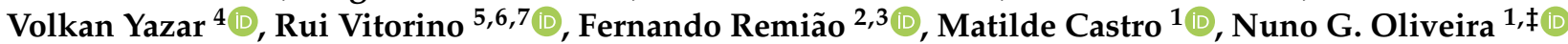 \\ and Joana P. Miranda $1, *, \ddagger$ (D)
}

\section{check for} updates

Citation: Serras, A.S.; Camões, S.P.; Antunes, B.; Costa, V.M.; Dionísio, F.; Yazar, V.; Vitorino, R.; Remião, F.; Castro, M.; Oliveira, N.G.; et al. The Secretome of Human Neonatal Mesenchymal Stem Cells Modulates Doxorubicin-Induced Cytotoxicity: Impact in Non-Tumor Cells. Int. J. Mol. Sci. 2021, 22, 13072. https:// doi.org/10.3390/ijms222313072

Academic Editor: Ahmad R. Safa

Received: 22 October 2021

Accepted: 28 November 2021

Published: 3 December 2021

Publisher's Note: MDPI stays neutra with regard to jurisdictional claims in published maps and institutional affiliations.

Copyright: (c) 2021 by the authors Licensee MDPI, Basel, Switzerland. This article is an open access article distributed under the terms and conditions of the Creative Commons Attribution (CC BY) license (https:// creativecommons.org/licenses/by/ $4.0 /$ )
1 Research Institute for Medicines (iMed.ULisboa), Faculty of Pharmacy, Universidade de Lisboa, 1649-003 Lisbon, Portugal; ana.serras@edu.ulisboa.pt (A.S.S.); sergiocamoes@campus.ul.pt (S.P.C.); bernardoantunes_94@hotmail.com (B.A.); mcastro@ff.ul.pt (M.C.); ngoliveira@ff.ul.pt (N.G.O.)

2 Associate Laboratory i4HB - Institute for Health and Bioeconomy, Faculty of Pharmacy, University of Porto, 4050-313 Porto, Portugal; veramcosta@ff.up.pt (V.M.C.); fdionisio@ff.up.pt (F.D.); remiao@ff.up.pt (F.R.)

3 UCIBIO_Applied Molecular Biosciences Unit, Laboratory of Toxicology, Department of Biological Sciences, Faculty of Pharmacy, University of Porto, 4050-313 Porto, Portugal

4 Institute for Cell Engineering, Johns Hopkins School of Medicine, Baltimore, MD 21205, USA; volkanyazar1984@gmail.com

5 LAQV-REQUIMTE, Mass Spectrometry Center, Department of Chemistry, University of Aveiro, 3810-193 Aveiro, Portugal; rvitorino@ua.pt

6 Cardiovascular R\&D Center, Department of Surgery and Physiology, Faculty of Medicine, University of Porto, 4200-319 Oporto, Portugal

7 iBiMED, Department of Medical Sciences, University of Aveiro, 3810-193 Aveiro, Portugal

* Correspondence: jmiranda@ff.ul.pt

+ These authors contributed equally to this work.

$\ddagger$ Both authors supervised this work.

Abstract: Doxorubicin (Dox) is one of the most widely used treatments for breast cancer, although limited by the well-documented cardiotoxicity and other off-target effects. Mesenchymal stem cell (MSC) secretome has shown immunomodulatory and regenerative properties, further potentiated under 3D conditions. This work aimed to uncover the effect of the MSC-derived secretome from 3D (CM3D) or 2D (CM2D) cultures, in human malignant breast cells (MDA-MB-231), non-tumor breast epithelial cells (MCF10A) and differentiated AC16 cardiomyocytes, co-treated with Dox. A comprehensive proteomic analysis of CM3D/CM2D was also performed to unravel the underlying mechanism. CM3D/CM2D co-incubation with Dox revealed no significant differences in MDA-MB-231 viability when compared to Dox alone, whereas MCF10A and AC16 viability was consistently improved in Dox+CM3D-treated cells. Moreover, neither CM2D nor CM3D affected Dox anti-migratory and anti-invasive effects in MDA-MB-231. Notably, Ge-LC-MS/MS proteomic analysis revealed that $\mathrm{CM} 3 \mathrm{D}$ displayed protective features that might be linked to the regulation of cell proliferation (CAPN1, CST1, LAMC2, RANBP3), migration (CCN3, MMP8, PDCD5), invasion (TIMP1/2), oxidative stress (COX6B1, AIFM1, CD9, GSR) and inflammation (CCN3, ANXA5, CDH13, GDF15). Overall, CM3D decreased Dox-induced cytotoxicity in non-tumor cells, without compromising Dox chemotherapeutic profile in malignant cells, suggesting its potential use as a chemotherapy adjuvant to reduce off-target side effects.

Keywords: breast cancer; doxorubicin; cardiotoxicity; mesenchymal stem cells; secretome; 3D cultures

\section{Introduction}

Breast cancer is the most frequently diagnosed cancer and the second-leading cause of cancer death in women [1]. The use of anthracyclines, specifically doxorubicin (Dox) and epirubicin, is established as the first line of treatment in solid tumors such as breast 
cancer [2], as well as in adjuvant treatment. Dox, in particular, acts mainly by inducing DNA damage, inhibiting cancer cell proliferation, inducing cell cycle arrest and apoptosis. Although the exact mechanisms involved are not fully understood, it is well-established that Dox inhibits topoisomerase II $\alpha$, intercalates in DNA strands and stimulates the generation of reactive oxygen species (ROS) [3-5].

Despite its tumor-killing effect, Dox is also associated with several dose-related side effects in off-target non-tumor cells of which cardiotoxicity stands out [6]. Unquestionably, Dox-induced cardiotoxicity greatly impacts its clinical use, affecting the quality of life of patients and often leading to life-threatening conditions [6,7]. The mechanisms of Doxmediated cardiomyopathy are multifactorial and not completely established. Despite the fact that inhibition of topoisomerase II $\beta$ has been recently described in the heart $[3$, 5], the most studied mechanisms are oxidative stress and dysfunction of mitochondrial bioenergetics (also via topoisomerase II $\beta$ ) [3,7-11]. Dox largely accumulates on cardiac tissue because of its affinity to cardiolipin and a higher sensitivity to oxidative insult [7]. As such, myocardial tissues are more susceptible to the effects of Dox. Moreover, unlike non-tumor cells, cancer cells are able to shift their metabolism and to mediate defensive mechanisms against ROS, through, e.g., preferential energy dependence on glycolysis, or by increasing multidrug resistance (MDR) transporters that exclude oxidative stress-generated by-products [12-14]. In this context, Dox displays different mechanisms in tumor and nontumor cells, which may create opportunities to develop novel adjuvant strategies, aiming at decreasing off-target toxicity of Dox while not interfering with its chemotherapeutic activity.

Different approaches have explored mesenchymal stem/stromal cells (MSCs) for their unique immunomodulatory and anti-inflammatory properties, targeting a wide range of diseases, including cardiomyopathy [11,15-18]. MSCs have also been regarded as possible anticancer therapeutic agents since they exhibit an intrinsic ability to migrate towards tumors in which they secrete antineoplastic factors such as IFN- $\alpha / \beta$ [19]. Interestingly, some studies have reported a pro-tumorigenic role of MSCs [20-24], while others describe MSCs as tumor inhibiting agents [25-31], both in vitro and in vivo. Although yet unclear, some aspects, including MSC tissue of origin, cancer type and experimental methodologies adopted (i.e., the use MSCs per se vs. their secretome) have been suggested as playing a key role in the distinct outcomes reported. Indeed, studies involving umbilical cord (UC)-derived MSCs have usually shown to inhibit cancer growth as opposed to bone marrow (BM)- or adipose tissue (AT)-derived MSCs [23,24,28-32]. In addition, when exposed to a cancer-like environment, MSCs may differentiate into tumor supporting cells, such as tumor-associated fibroblasts (TAFs) [32], raising concerns about the use of these cells per se. Importantly, an overall anti-tumor effect of MSCs is often observed when its secretome/conditioned media (CM) is administered to tumor cells, thus pending the balance towards the development of novel cell-free based therapies [29,31].

The secretome of MSCs has previously been shown to attenuate cardiac remodeling and preserve cardiac function in a murine myocardial infarction model by reducing cardiomyocyte apoptosis, promoting capillary-like structure formation by endothelial cells and stimulating resident cardiac progenitor cell proliferation and activation [17]. Moreover, it has been reported that the modulation of the MSC culture conditions by resorting to three-dimensional (3D) systems allows the production of a secretome with enhanced therapeutic properties $[16,18,33]$. In sum, innovative approaches are clearly needed to shed light on the usefulness of CM from both 2D and 3D MSC cultures in the context of Dox-induced effects in both cancer and normal-type cells. In this context, the present study aimed for the first time to uncover the role and to evaluate the effect of the secretome of MSCs in human malignant breast cells and non-tumor cells (i.e., normal breast epithelial cells and cardiomyocytes) upon co-treatment with Dox, further unraveling the putative underlying mechanisms, through a comprehensive mechanistic proteomic analysis. 


\section{Results}

\subsection{MSC Conditioned Media Encloses Proteins Involved in Cytoprotection}

Recent knowledge supports that the mechanism of action of MSCs is mostly due to its paracrine effect rather than the cells per se. As such, in order to understand if the protein content of MSC CM (CM2D and CM3D) could suggest a role and justify or support its use as an adjuvant in breast cancer treatment, a Ge-LC-MS/MS proteomics followed by an Ingenuity Pathway Analysis (IPA) of both CM2D and CM3D was performed. As a result, a total of 1165 distinct proteins were identified, 1106 proteins within CM3D and 831 proteins within $\mathrm{CM} 2 \mathrm{D}$, showing also that both $\mathrm{CM}$ encompassed specific sets of proteins. Specifically, 772 proteins were found in CM3D and CM2D, whereas 334 proteins were identified as unique to CM3D and only 59 proteins unique to CM2D (Figure 1A).

The proteomic data analyzed by IPA allowed the identification of several proteins within the MSC secretome (CM2D and CM3D) involved in important biological processes. Specifically, a deeper analysis was focused on essential processes involved in cytoprotection and tumor development, e.g., cell proliferation, migration and invasion, inflammation and oxidative stress. Both CM presented proteins involved in proliferation of both tumor and non-tumor cells, of which CAPN1, CST1, LAMC2 and RANBP3 stood out in CM3D and GPC6, ILK, MAPK1, MIF and PICALM in CM2D. In addition, both CM presented a remarkable quantity of different proteins that have been associated with antioxidant and/or anti-inflammatory effects and may thus mediate the viability of non-tumor cells, such as AIFM1, ANXA5, CD9, CDH13, GDF15, GSR and TIMP2. Additionally, comparing both $\mathrm{CM}$, a higher proportion of proteins with these properties were identified to be unique to CM3D, such as COX6B1, CCN3 and S100A16, whereas only MIF and SDC4 were unique to CM2D. Regarding cell migration, cytokines such as TGFB and IL6 are common to both CM, whilst proteins such as CCN3, MMP8, PDCD5 have been identified to be unique to CM3D and associated with decreased cell migration. In addition, GPC6, ILK, MAPK1, MIF and SDC4 were unique to CM2D, being linked to increased cell migration. Lastly, cell invasion is known to be regulated by proteins that were identified in both CM such as TIMP1 and TIMP2. Among those proteins, CAPN1 (cell proliferation) and CCN3 (inflammation and cell migration), exclusive for 3D samples; MIF (cell proliferation, migration and invasion), exclusive for 2D samples and GDF15 (inflammation), TGFB (cell proliferation) and CD9 (antioxidant and/or anti-inflammatory effects) for both samples were chosen for validation of the proteomic data by Western blot analysis (Figure 1B).

IPA analysis of the secretome of MSCs also established protein-protein interaction networks. CM3D unique proteins formed a network related to cancer, carbohydrate metabolism and cardiovascular disease (Figure 1C), whereas mainly CM3D and CM2D shared proteins comprising a network related to the cardiovascular system development and function, cellular movement and tissue development (Figure 1D). Both networks are intimately associated with cell growth and survival and consistently suggest AKT, a serine/threonine-protein kinase, as a key player for the functional protein interactions involved in these biological processes. AKT kinase is involved in the regulation of various signaling downstream pathways including metabolism, cell proliferation, survival, growth and angiogenesis. The AKT kinase pathway stands among the most important components of the cell proliferation mechanism. 

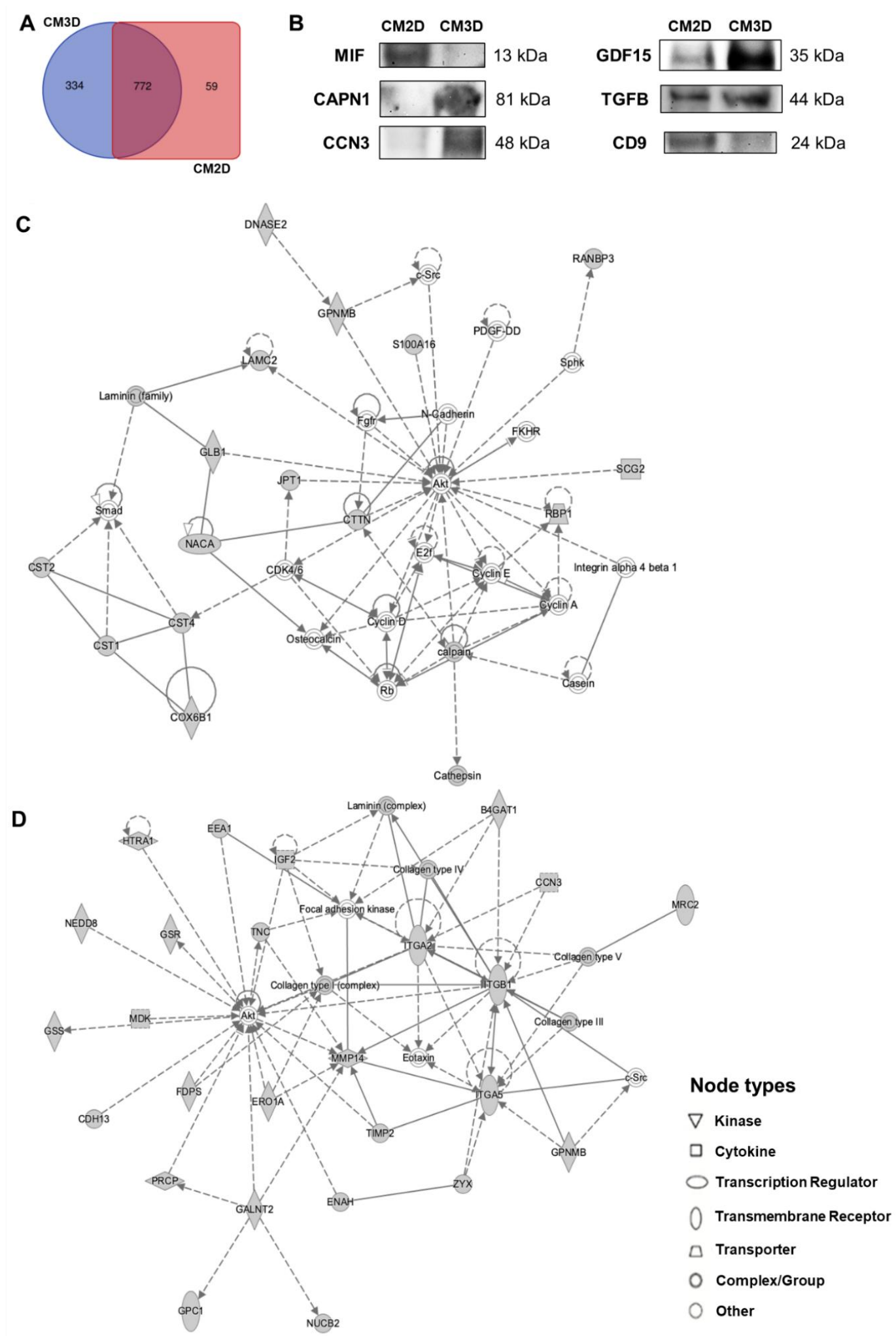

Figure 1. Proteomic profiling of MSC CM revealed the presence of proteins involved in cytoprotection. (A) Venn diagram shows the unique and shared protein numbers identified in CM3D and CM2D. (B) Confirmation of selected proteomic data by Western blot analysis of CAPN1, CCN3, MIF, GDF15, TGFB and CD9. (C) Network analysis of proteinprotein interactions within $\mathrm{CM} 3 \mathrm{D}$ with functions associated with cancer, carbohydrate metabolism and cardiovascular disease performed using the IPA software. (D) Network analysis of protein-protein interactions within CM3D unique and shared proteins with functions associated with the cardiovascular system development and function, cellular movement and tissue development performed using the IPA software. CM2D, conditioned medium derived from 2D cultures; CM3D, conditioned medium derived from 3D cultures; IPA, Ingenuity Pathway Analysis. 
2.2. The Effect of Doxorubicin in the Viability, Migration and Invasion of MDA-MB-231 Cells Is Maintained When Co-Administered with MSC Secretome

In order to understand if MSC CM could indeed result in biological effects, the outcome of administering MSC CM concomitantly with Dox was evaluated in both tumor (MDA-MB-231 cells) and non-tumor (MCF10A and AC16) cells (see following sections).

The effect of concomitant exposure of CM3D or CM2D and Dox on the cell viability of the triple negative invasive breast cancer (TNBC) cell line MDA-MB-231 was assessed through a $48 \mathrm{~h}$ MTS assay. As expected, the exposure of human cancer cells to Dox led to a concentration-dependent cytotoxicity (Figure 2). Importantly, the same cytotoxic trend was observed upon combinatory exposure to CM2D or CM3D and Dox.

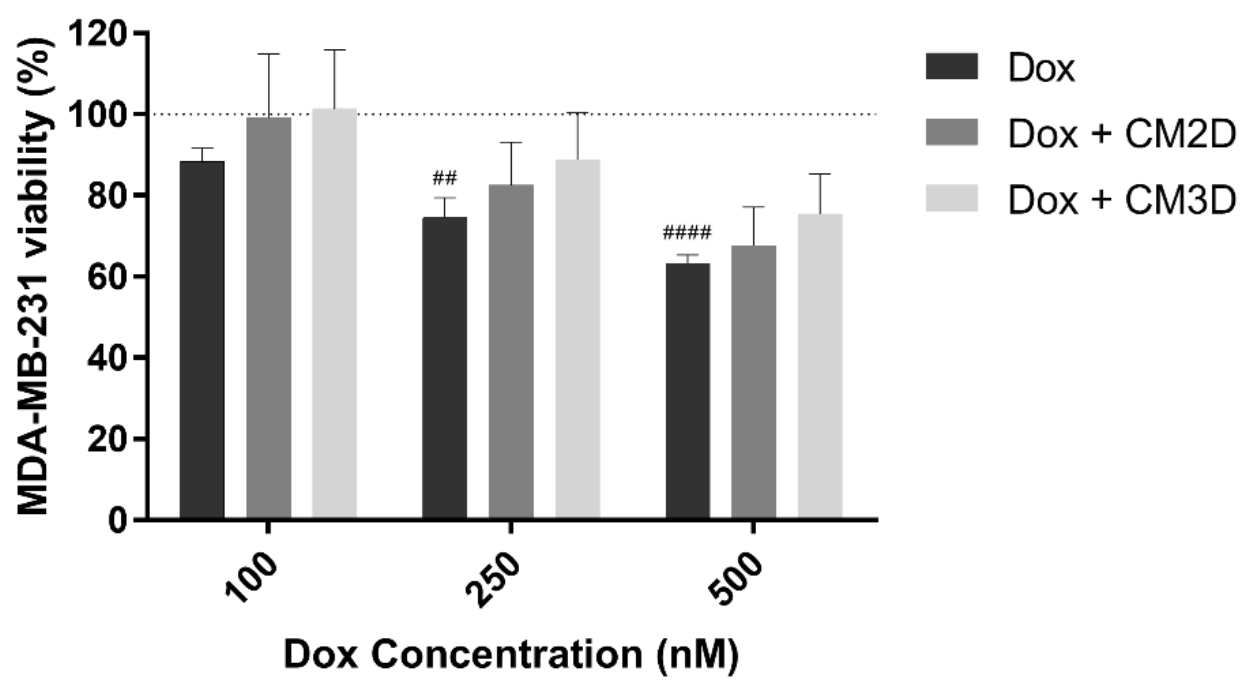

Figure 2. Exposure of MDA-MB-231 cells to MSC CM did not significantly affect the cytotoxic effect of Dox. MDA-MB-231 cells were incubated with 0-500 nM of Dox and both conditioned media, CM2D or CM3D, and cytotoxicity was evaluated by MTS reduction assay. Cell viability is expressed in percentage (mean $\pm \mathrm{SD}, \mathrm{n}=3-6$ ) to non-treated MDA-MB-231 cells (control). Grid line represents $100 \%$ cell viability (control). Statistical significance is expressed relative to control of non-treated cells, i.e., $100 \%$ viability as ${ }^{\# \#} p<0.01, \# \# \#$, 0.0001 . CM2D, conditioned medium derived from 2D cultures; CM3D, conditioned medium derived from 3D cultures; Dox, doxorubicin.

The relative capacity of CM3D/CM2D in combination with Dox (100 nM) to influence MDA-MB-231 cell migration and invasion was also evaluated by in vitro scratch and transwell assays, respectively, and compared to Dox alone (Figures 3 and 4). Importantly, under these conditions, a non-cytotoxic concentration of Dox $(100 \mathrm{nM})$ was adopted in both assays in order to guarantee that the observed results are due to a migratory or invasive effect rather than cell viability. Figure 3B shows representative images of MDA-MB-231 cell migration at 0,20 and $30 \mathrm{~h}$ after scratch where no statistical significance was observed between combinatory treatment of Dox and CM3D/CM2D and Dox alone (Figure 3A). Likewise, the co-administration of CM with Dox did not alter the effect of Dox alone in the ability of MDA-MB-231 cells to invade surrounding tissues (Figure 4). 

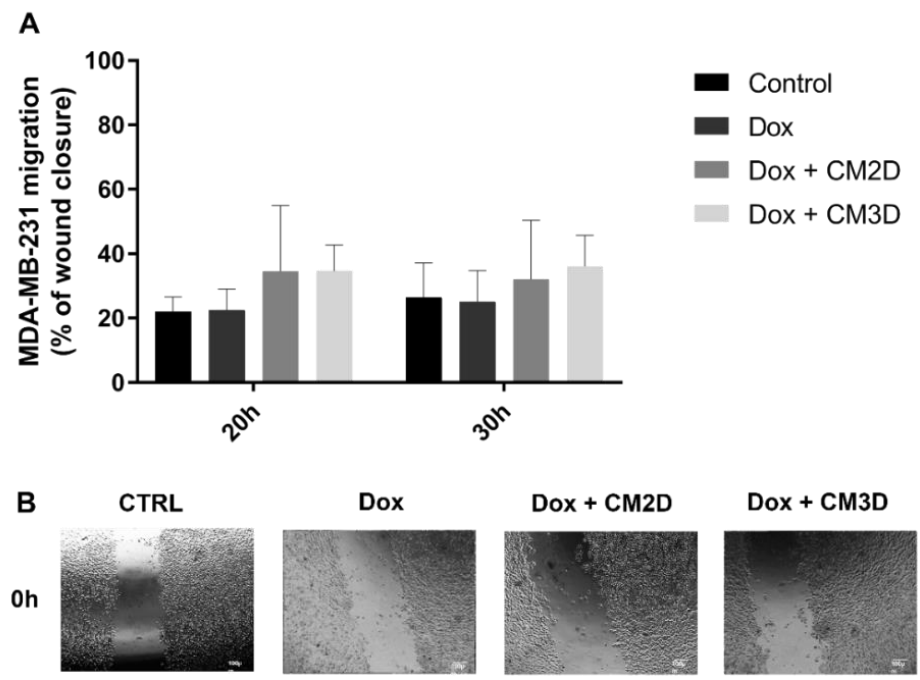

20h
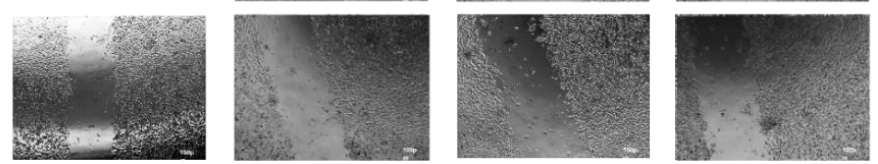

$30 \mathrm{~h}$
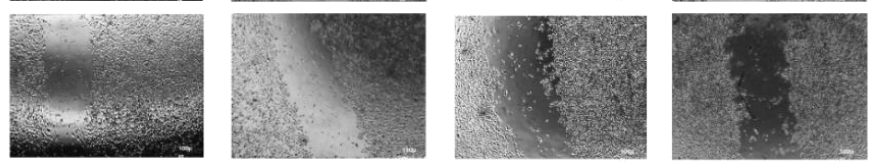

Figure 3. Co-exposure of MDA-MB-231 cells to Dox and MSC CM did not affect cell migration. (A) The effect of CM2D or CM3D in combination with Dox (100 nM) on the migration of MDAMB-231 cells at the 20 and $30 \mathrm{~h}$ time points was evaluated by scratch assay. Cell migration is represented as percentage (mean $\pm S D, n=3-6$ ) of wound closure at the defined time points. (B) Representative images of scratch assays of MDA-MB-231 cells incubated with or without MSC $\mathrm{CM}$ (control) immediately after the scratches were made $(0 \mathrm{~h})$ and after 20 and $30 \mathrm{~h}$. Magnification $4 \times$, scale bar $=100 \mu \mathrm{m}$. CM2D, conditioned medium derived from 2D cultures; CM3D, conditioned medium derived from 3D cultures; Dox, doxorubicin.

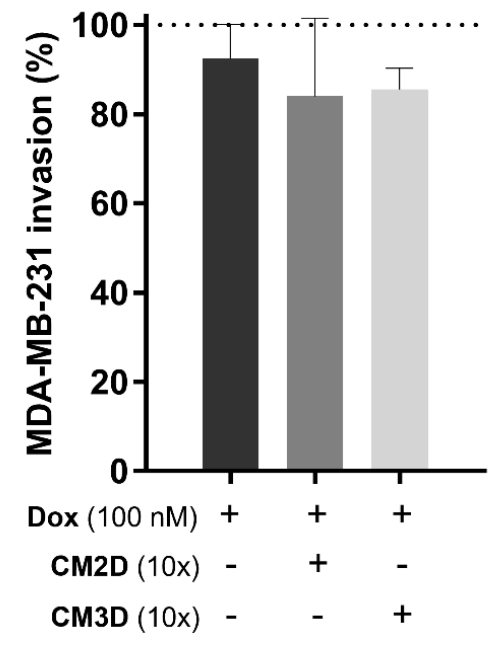

Figure 4. Co-exposure of MDA-MB-231 cells to CM3D or CM2D maintained the anti-invasion effect of Dox. The effect of CM2D or CM3D in combination with Dox (100 nM) on the chemoinvasion ability of MDA-MB-231 cells was evaluated by transwell assay. Results are expressed in percentage to control (mean $\pm \mathrm{SD}, \mathrm{n}=4-6$ ). Grid line represents 100\% cell viability (control). CM2D, conditioned medium derived from 2D cultures; CM3D, conditioned medium derived from 3D cultures; Dox, doxorubicin. 


\subsection{MSC Secretome Ameliorates the Cytotoxic Effect of Doxorubicin in Non-Tumor Breast Epithelial Cells}

To assess the effect of the secretome of MSCs on the cytotoxicity of Dox in nontumor breast epithelial MCF10A cells, a MTS assay was used. Similar to tumor cells, Dox exposure led to a concentration-dependent effect on cell viability (Figure 5). Conversely, the concomitant exposure of MCF10A cells to Dox and CM3D resulted in an increase in the percentage of cell viability of approximately $32 \pm 6 \%(p<0.0001)$ and $16 \pm 2 \%$ $(p<0.05)$ for Dox concentrations of 100 and $250 \mathrm{nM}$, respectively, when compared to cells treated with Dox. This beneficial effect was also observed, although to a lesser extent, within combinatory treatment of Dox and CM2D with an enhanced cell viability of $19 \pm 5 \%(p<0.01)$ and $15 \pm 4 \%(p<0.05)$, for 100 and $250 \mathrm{nM}$ of Dox, respectively.

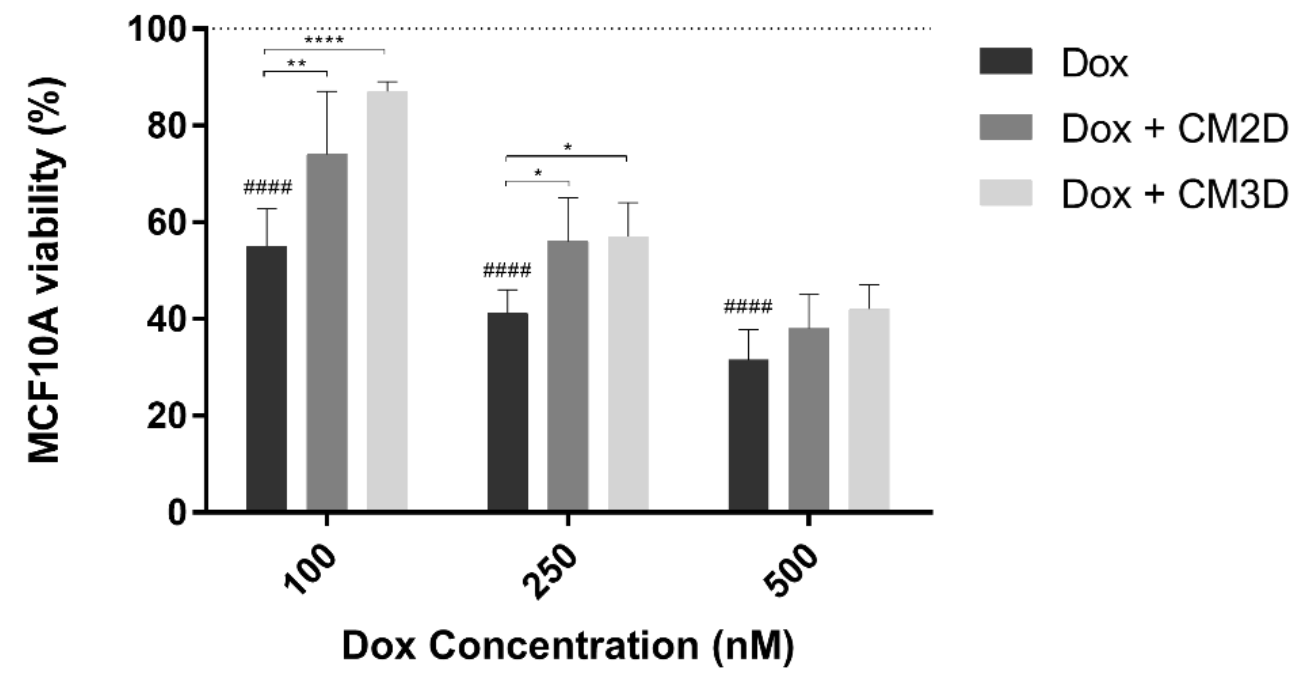

Figure 5. Combinatory exposure of MCF10A cells to MSC CM increased the viability of nontumor breast cells exposed to Dox. The MCF10A cells were incubated with 0-500 nM of Dox alone and in combination with both conditioned media, CM2D or CM3D, and evaluated by MTS reduction assay. Cell viability is expressed in percentage (mean $\pm \mathrm{SD}, \mathrm{n}=3-6)$ to non-treated MCF10A (control). Grid line represents $100 \%$ cell viability (control). Statistical significance is expressed relative to Dox as ${ }^{*} p<0.05,{ }^{* *} p<0.01,{ }^{* * *} p<0.0001$ and to control of non-treated cells, i.e., $100 \%$ viability as \#\#\#\# $p<0.0001$. CM2D, conditioned medium derived from 2D cultures; CM3D, conditioned medium derived from 3D cultures; Dox, doxorubicin.

2.4. The Cytotoxic Effect of Doxorubicin on Cardiomyocytes Is Ameliorated by the MSC Secretome from $3 D$ Cultures

To evaluate the effect of the CM2D/CM3D on Dox-treated cardiomyocytes, AC16 differentiated cells were used to establish an in vitro cardiac model [34]. Dox exposure led to a decrease in cell viability of approximately $20 \pm 5 \%(p<0.0001$; Figure 6$)$. Moreover, the concomitant exposure to CM2D and Dox did not show significant improvement in cell survival ( $82 \pm 7 \%$ Dox and CM2D vs. $80 \pm 5 \%$ Dox alone; n.s.). On the other hand, the combinatory treatment of Dox and CM3D presented a significantly higher cell viability when compared to the group treated with Dox alone $(87 \pm 7 \%$ Dox and CM3D, $p<0.01)$ or with Dox and CM2D $(p<0.01)$, emphasizing the beneficial effect of CM3D (Figure 6). 


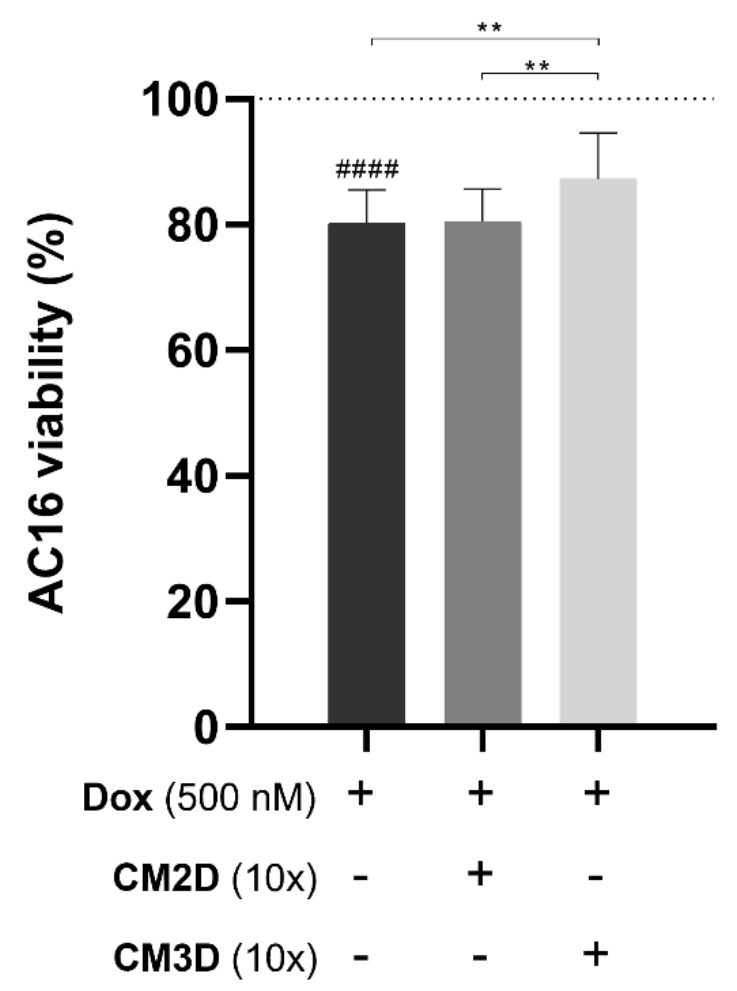

Figure 6. Exposure of AC16 cardiomyocyte cells to CM3D increased the viability of cells exposed to Dox. The differentiated AC16 cells were incubated with $500 \mathrm{nM}$ of Dox alone or in combination with CM2D or CM3D being the cytotoxicity evaluated by MTS reduction assay. Cell viability is expressed in percentage (mean $\pm \mathrm{SD}, \mathrm{n}=3-6$ ) to non-treated differentiated AC16 cells (control). Grid line represents $100 \%$ cell viability (control). Statistical significance is expressed relative to Dox as ** $p<0.01$ and to control of non-treated cells, i.e., 100\% viability as ${ }^{\# \# \# ~} p<0.0001$. CM2D, conditioned medium derived from 2D cultures; CM3D, conditioned medium derived from 3D cultures; Dox, doxorubicin.

\section{Discussion}

The side effects linked to the chemotherapeutic treatment of breast cancer with doxorubicin remain a major clinical concern. The application of the secretome of MSCs has been investigated regarding its active role in immunomodulation and regeneration processes $[15-18,35]$, outlining its great potential in several pathological conditions. However, its effects within cancer setting have not yet been determined. In this study, we aimed at understanding the impact of the secretome of MSCs in combination with clinically relevant doses of Dox in both tumor and non-tumor cells.

According to our findings, neither CM3D nor CM2D significantly interfered with Dox treatment regarding cancer cell viability, the first indicator of safety for applicability in these conditions. Hendijani et al. have also found that the CM of MSCs did not promote tumor cell growth or resistance to Dox in lung cancer cells [36]. Remarkably, herein, CM presented a cytoprotective effect towards Dox cytotoxicity more pronounced in non-tumor breast epithelial cells and cardiomyocytes than in breast cancer cells. Hence, we firstly hypothesize that MSC CM comprises pro-proliferative factors. Indeed, several pro-proliferation proteins were uniquely identified in CM2D such as PICALM, which positively regulate cell proliferation [37] and GPC6, MAPK1, ILK and MIF, all involved in cell proliferation, migration and invasion, including that of tumor cells [38-42], cardiomyocytes and endothelial cells $[38,39]$. Several proteins were also uniquely identified in CM3D, such as RANBP3, involved in cell proliferation by negative regulation of TGF- $\beta$ signaling [43]; CAPN1, mediating cell apoptosis, survival and migration [44] and CST1 and LAMC2, both involved in positive cell proliferation, migration and invasion $[45,46]$. Interestingly, as shown in both IPA-generated networks, most of the proteins identified 
in this study have been reported to modulate or be modulated by AKT. Indeed, the AKT signaling pathway is involved in cell death and survival responses of both tumor and non-tumor cells by induction of pro-angiogenic factors and inhibition of autophagy and pro-apoptotic factors [47]. Thus, all these proteins highlight the potential role of the MSC $\mathrm{CM}$ as modulator of cell proliferation and survival.

Reported differences in Dox mechanism of toxicity between non-tumor and tumor cells may be linked to distinct responses of cancer and non-tumor cells to oxidative stress [12]. Dox anticancer effects are mainly related to topoisomerase II $\alpha$ inhibition rather than this pro-oxidant effect [3,5], whereas in non-tumor cells, topoisomerase II $\beta$ inhibition and oxidative stress are considered the main mechanisms [3,7-11]. Zhang et al. [35] have reported that CM from induced pluripotent stem cell-derived MSCs (iMSCs) effectively decreased ROS formation in cardiac cells treated with Dox when compared to the drug alone, mainly through the secretion of MIF and GDF15. Thus, a second mechanism of the MSC secretome, besides stimulating cell proliferation, may be behind these distinct effects. In this study, MIF and GDF15 were identified in CM2D and in both MSC CM, respectively. Moreover, proteins found in both CM such as AIFM1, CD9 and GSR have been associated with the maintenance of the redox status [48-50], whilst ANXA5, CDH13, GDF15 and TIMP2 have shown not only antioxidant but also anti-inflammatory effects [35,51-54]. Notwithstanding, CM3D consistently showed better results when in combination with Dox compared to the effect of CM2D and Dox. When cultured in 3D conditions, MSCs displayed increased secretion of pro-angiogenic and anti-fibrotic factors, e.g., VEGF, FGF-2 and HGF, when compared to cells in traditional 2D cultures [16,18,33,55]. Furthermore, upon proteomic analysis of CM3D, a variety of proteins stood out, including CCN3, a pro-angiogenic, anti-inflammatory and anti-fibrotic protein [56,57], COX6B1 that has been shown to reduce cell apoptosis and ROS levels in non-tumor cells by regulation of mitochondrial function [58], and S100A16, involved in cardiomyocyte apoptosis and cardiac hypertrophy reduction [59]. Within CM2D, fewer proteins such as SDC4, which presents anti-apoptotic and anti-hypertrophic effects in the heart [60], and MIF were identified. All these MSC-secreted factors may have contributed to the enhanced viability of non-tumor cells, particularly in the case of CM3D. This adds strength to the assumption that the secretome obtained from MSCs in 3D cultures is more physiologically relevant.

Along with cell proliferation, cell migration and invasion are also essential to understand the effect of CM when concomitantly added with Dox to tumor cells. Scratch assay results showed that MDA-MB-231 migration ability was slightly increased, although non-significant, upon treatment with Dox and CM2D or CM3D. IL-6 has been reported to be present in higher levels in CM2D than in CM3D [18] and has also been associated with the stimulation of the migration of breast cancer cells by induction of AKT, MAPK and STAT3 phosphorylation [61]. Moreover, proteins exclusively identified in CM2D such as GPC6, ILK, MAPK1, MIF and SDC4 have been associated with positive regulation of cell migration [38-40,42,62]. On the other hand, CCN3, PDCD5 and MMP8 were found to be uniquely identified in CM3D and have been associated with negative regulation of cell migration [63-65]. Metalloproteinases (MMPs) have been correlated with increased tumor cell migration and invasion through degradation of the basement membrane. However, it has been suggested that MMP-8 has a tumor suppressive role in breast cancer cells that, in contrast to gastric and liver tumors, leads to inhibition of migration, invasion and metastasis, both in vitro and in vivo [64]. This interesting role in breast cancer may be due to the inhibition of TGF- $\beta$ with subsequent activation of programmed cell death 4 (PDCD4), decrease of MMP-3 and MMP-9 and increase of cell adhesion [64].

It is worth mentioning that cell migration and invasion are two distinct events within cancer progression and metastization [66]. An important anti-invasion mechanism of Dox has been reported to be the downregulation of MMPs [67]. Clarke et al. [29] found that the presence of TIMP-1 and TIMP-2, which are inhibitors of MMPs, in the secretome of immortalized BM-MSC led to the inhibition of breast cancer cell movement, with a better response towards invasiveness than migration. Indeed, our proteomic analysis 
identified TIMP1 and TIMP2 in both CM, which may thus exert a cumulative effect on the downregulation of MMPs induced by Dox.

Overall, our results showed that the secretome of MSCs exhibited different effects in tumor and non-tumor cells. When combined with Dox, the MSC secretome did not significantly affect its cytotoxic, anti-migration or anti-invasive effects. Moreover, a partial but significant protection in cell viability was observed in both MCF10A and AC16 cells upon concomitant treatment, while the Dox-related cytotoxic effect was maintained in MDA-MB-231 cells. Importantly, CM3D consistently showed better results than CM2D, and several proteins were identified which may be related to these differential effects. These results may lead the way for the use of the secretome of MSCs, specifically from 3D cultures, to reduce the undesirable side effects of Dox without compromising its anticancer activity.

\section{Materials and Methods}

\subsection{Reagents}

Minimum essential medium Eagle alpha modification ( $\alpha$-MEM), Dulbecco's modified Eagle's medium (DMEM), Ham's F-12 nutrient mixture medium (F12), penicillinstreptomycin solution, insulin solution from bovine pancreas, hydrocortisone, cholera toxin, human epidermal growth factor, gelatin, fibronectin and Dox were obtained from SigmaAldrich (St. Louis, MO, USA). Horse and fetal bovine sera (FBS) and trypsin/ethylenediamine tetraacetic acid (EDTA) solution were obtained from Gibco ${ }^{\circledR}$ (Thermo Fisher Scientific, Waltham, MA, USA). 3-(4,5-dimethylthiazol-2-yl)-5(3-carboxymethonyphenol)-2(4-sulfophenyl)-2H-tetrazolium (MTS) was purchased from Promega (Madison, WI, USA). An $800 \mu \mathrm{M}$ stock solution of doxorubicin hydrochloride (Dox) was prepared in $\mathrm{H}_{2} \mathrm{O}$ MilliQ, aliquoted and stored at $-20^{\circ} \mathrm{C}$ until further use.

\subsection{MSC Isolation}

This study was approved by the Ethics Committee of the Hospital Dr. José de Almeida (Cascais, Portugal), in the scope of a research protocol between ECBio (Research \& Development in Biotechnology, S.A.) and HPP Saúde (Parcerias Cascais, S.A.). Umbilical cord donations, with written informed consent, as well as umbilical cord procurement were carried out according to Directive 2004/23/EC of the European Parliament and of the Council of 31 March 2004 on setting standards of quality and safety for the donation, procurements, testing, processing, preservation, storage and distribution of human tissues and cells. MSCs are a population of umbilical cord tissue-derived human neonatal mesenchymal stromal cells and were isolated as described in the patent $\mathrm{WO} / 2009 / 044379$, developed by ECBio, S.A. [68] from umbilical cords of healthy new-born babies, upon informed consent of healthy parturients, as previously described [69]. Cells were cryopreserved in $\alpha$-MEM containing $10 \%$ dimethyl sulfoxide (DMSO) stock solution and $20 \%$ FBS, using a controlled rate of temperature decrease. When needed, MSCs cryopreserved between passage $(\mathrm{P}) 3$ and P5 were thawed and further expanded. MSCs keep their phenotype until at least 55 cPDs (P22) before reaching senescence [16].

\subsection{Conditioned Media Production from MSC Cultures}

The production of conditioned media from 2D cultures (CM2D) and 3D cultures (CM3D) was performed according to a previously optimized protocol $[16,18]$. Both types of $\mathrm{CM}$ were produced from cells having undergone the equivalent number of cPDs; equivalent cell/volume ratio, i.e., the volume for CM3D production was adjusted to obtain a conditioning volume per cell equivalent to that in the $2 \mathrm{D}$ system and the same conditioning time ( $48 \mathrm{~h}$ ). For the production of CM2D, cells were seeded at an inoculum of $1 \times 10^{4}$ cells $/ \mathrm{cm}^{2}$ in $175 \mathrm{~cm}^{2} \mathrm{t}$-flasks and maintained in medium supplemented with 5\% FBS until reaching $90 \%$ confluence, generally at day 3 . After carefully washing the cells, medium was replaced by $\alpha$-MEM without FBS, at a final volume of $25 \mathrm{~mL}$. After a $48 \mathrm{~h}$ conditioning period, CM2D was collected under sterile conditions. CM3D was obtained through the cell inoculation and expansion according to [16,18]. After $24 \mathrm{~h}$, FBS concentration was reduced to $5 \%$, and 
the cells were maintained in these conditions for 3 days. At day 5, medium was replaced by $\alpha$-MEM without FBS. After a $48 \mathrm{~h}$ conditioning period, CM3D was then collected under sterile conditions. CM3D and CM2D were used at a final concentration of $10 \times$, achieved by using 3 kDa cut-off centrifugal concentrators (Millipore ${ }^{\circledR}$, Merck, Darmstadt, Germany) as per manufacturer's recommendations. The control consisted of MSC medium, which was never in contact with cells. All samples were stored aseptically at $-80^{\circ} \mathrm{C}$ until further use.

\subsection{LC-MS/MS Analysis}

A total of $30 \mu \mathrm{g}$ of each sample was isolated, and the volume was adjusted to $300 \mu \mathrm{L}$ with $4 \%$ SDS in $0.5 \mathrm{M}$ Tris $\mathrm{pH}$ 6.8. A total of 6 samples were prepared for LC-MS/MS analysis with the S-Trap ${ }^{\circledR}$ Micro Spin Column (Protifi, Farmingdale, NY, USA) digestion protocol according to the manufacturer's instructions with slight modifications. Briefly, all samples were centrifuged for $8 \mathrm{~min}$ at $13,000 \times g$, and proteins in the supernatant were first reduced by addition of $20 \mathrm{mM}$ DTT and incubation for $10 \mathrm{~min}$ at $95{ }^{\circ} \mathrm{C}$ and then alkylated by addition of $40 \mathrm{mM}$ iodoacetamide and incubation for $30 \mathrm{~min}$ at RT in the dark. Proteins were digested with trypsin (Promega; $1 / 25, w / w$ ) by adding trypsin in $50 \mathrm{mM}$ TEAB solution to the micro column for $1 \mathrm{~h}$ at $47^{\circ} \mathrm{C}$. Peptides were eluted according to the manufacturer's instructions.

Purified peptides were dried and re-dissolved in solvent A $(0.1 \%$ trifluoroacetic acid (TFA) in water/acetonitrile (ACN;98:2, v/v)), and approximately $2 \mu \mathrm{g}$ of each sample was injected for LC-MS/MS analysis on an Ultimate 3000 RSLC nanoLC (Thermo Fisher Scientific) in-line connected to an LTQ-Orbitrap Elite (Thermo Fisher Scientific). Trapping was performed at $10 \mu \mathrm{L} / \mathrm{min}$ for $4 \mathrm{~min}$ in solvent $\mathrm{A}$ on a $20 \mathrm{~mm}$ trapping column (made in-house, $100 \mu \mathrm{m}$ internal diameter, $5 \mu \mathrm{m}$ beads, C18 Reprosil-HD, Dr. Maisch, Germany), and the sample was loaded on a $200 \mathrm{~cm}$ long micro pillar array column (PharmaFluidics, Ghent, Belgium) with C18-endcapped functionality mounted in the Ultimate 3000's column oven at $50{ }^{\circ} \mathrm{C}$. For proper ionization, a fused silica PicoTip emitter (10 $\mu \mathrm{m}$ inner diameter; New Objective, Littleton, MA, USA) was connected to the $\mu$ PAC ${ }^{\circledR}$ outlet union, and a grounded connection was provided to this union. Peptides were eluted by a non-linear increase from 1 to $55 \%$ MS solvent B [0.1\% formic acid (FA) in water/ $\operatorname{ACN}(2: 8, v / v)]$ over $115 \mathrm{~min}$, first at a flow rate of 750 then at $300 \mathrm{~nL} / \mathrm{min}$, followed by a 15-min wash reaching $99 \%$ MS solvent B and re-equilibration with MS solvent A ( $0.1 \%$ FA in water).

The mass spectrometer was operated in data-dependent, positive ionization mode, automatically switching between MS and MS/MS acquisition for the 20 most abundant peaks in a given MS spectrum. The source voltage was set to $2.7 \mathrm{kV}$, and the capillary temperature was $275^{\circ} \mathrm{C}$. In the LTQ-Orbitrap Elite, full scan MS spectra were acquired in the Orbitrap ( $\mathrm{m} / \mathrm{z} 300-2000$, automatic gain control) with a resolution of $60,000($ at $400 \mathrm{~m} / \mathrm{z})$. The 20 most intense ions fulfilling predefined selection criteria were then isolated in the linear ion trap and fragmented in the high-pressure cell of the ion trap.

\subsection{MS Data Analysis}

The mass spectrometry proteomics data have been deposited in the ProteomeXchange Consortium via the PRIDE [70] partner repository with the dataset identifier PXD029795. Data analysis was performed with MaxQuant (version 1.6.8.0) using the Andromeda search engine with default search settings including a false discovery rate set at $1 \%$ on the PSM, peptide and protein level. Spectra were searched against the human protein sequences in the Uniprot database (database release version of June 2018), containing 20,960 sequences (www.uniprot.org, accessed on 16 December 2020). The mass tolerance for precursor and fragment ions was set to 4.5 and 20 ppm, respectively, and enzyme specificity was set as C-terminal to arginine and lysine, with a maximum of two missed cleavages. Variable modifications were set to oxidation of methionine residues and acetylation of protein $\mathrm{N}$ termini, while carbamidomethylation of cysteine residues was set as a fixed modification. 


\subsection{Ingenuity Pathway Analysis (IPA)}

Gene symbols of the significant proteins identified were uploaded to the Ingenuity Pathway Analysis (IPA v10.2020, QIAGEN, Hilden, Germany) server for in-depth knowledge analysis using the "Core Analysis" function (Fisher's exact test (FET) $p$-value: $1 \times 10^{-3}$ ). The upstream regulators were predicted by IPA using the default settings. The Venn diagram was generated using the "venn()" function in the R package gplots v3.0.1.1. The gene list enrichment analysis platform, EnrichR v01.07.2020 [71], at https:/ /amp.pharm.mssm.edu/Enrichr/ (accessed on 16 December 2021) was used with the following libraries in this study: DisGenNet RDF v7.0, Broad's Project Achilles, GO (v2015), Jensen Disease and Compartments (v2020), ReactomePA (v2015), WikiPathways (2019) and Pfam Domains (v2019). STRING v11 protein association network analysis was performed with a minimal interaction score of 0.400 (FET $p$-value: $1 \times 10^{-3}$ ) [72].

\subsection{In Vitro Cell Viability Assay}

The effect of CM2D and CM3D in cell viability, either alone or in combination with Dox, was evaluated in the two human mammary cell lines and in the differentiated human cardiomyocytes using the MTS reduction assay.

MDA-MB-231 and MCF10A were acquired from ATCC (Manassas, VA, USA) and seeded in 96-well plates at a density of $6.5 \times 10^{3} \mathrm{cells} / \mathrm{cm}^{2}$ and $4.0 \times 10^{3}$ cells $/ \mathrm{cm}^{2}$ per well, respectively, and kept in a humidified atmosphere at $37^{\circ} \mathrm{C}$ and $5 \% \mathrm{CO}_{2}$. MDA-MB-231 were cultured in DMEM supplemented with 10\% FBS and MCF10A in DMEM/F12 medium, containing $5 \%$ horse serum, $100 \mathrm{U} / \mathrm{mL}$ penicillin, $100 \mu \mathrm{g} / \mathrm{mL}$ streptomycin, $0.01 \mathrm{mg} / \mathrm{mL}$ insulin, $0.5 \mu \mathrm{g} / \mathrm{mL}$ hydrocortisone, $0.1 \mu \mathrm{g} / \mathrm{mL}$ cholera toxin and $20 \mathrm{ng} / \mathrm{mL}$ human epidermal growth factor. After $48 \mathrm{~h}$ of plating, cells were exposed to CM2D/CM3D $(10 \times$ concentrated) alone or in combination with Dox (100 to $500 \mathrm{nM})$ for $48 \mathrm{~h}$. Cells were also incubated with $\alpha$-MEM and $\mathrm{H}_{2} \mathrm{O}$ MilliQ (solvents for CM and Dox, respectively) in complete cell culture medium as controls. Afterwards, medium was discarded, $100 \mu \mathrm{L}$ of cell culture medium with $20 \mu \mathrm{L}$ of MTS was added and cells were incubated for $1 \mathrm{~h}$ at $37^{\circ} \mathrm{C}$, absorbance was measured at $490 \mathrm{~nm}$ using a microplate spectrophotometer (SPECTROstar Omega, BMG LABTECH, Offenburg, Germany). Three independent experiments in triplicates were performed. Results were expressed as percentage relative to control, which was considered as $100 \%$ cell viability.

AC16 human cardiomyocyte cells were used until the 10th passage as recommended [34] and were seeded at a density of $32.5 \times 10^{4}$ cells $/ \mathrm{cm}^{2}$ in gelatin- and fibronectin-coated 48 -well plates $(0.02 \%$ and $0.0005 \% w / v)$. AC16 cells were cultured in DMEM/F12 medium supplemented with $12.5 \% \mathrm{FBS}, 100 \mathrm{U} / \mathrm{mL}$ penicillin and $100 \mathrm{\mu g} / \mathrm{mL}$ streptomycin and kept at $37{ }^{\circ} \mathrm{C}$ in a humidified atmosphere with $5 \% \mathrm{CO}_{2}$ during the proliferative stage. After $24 \mathrm{~h}$, medium was changed to DMEM/F12 supplemented with $2 \%$ horse serum, $100 \mathrm{U} / \mathrm{mL}$ penicillin and $100 \mu \mathrm{g} / \mathrm{mL}$ streptomycin. After $24 \mathrm{~h}$ of differentiation, AC16 cells were incubated with Dox (100 to $500 \mathrm{nM})$ and/or CM2D/CM3D (10× concentrated) for $24 \mathrm{~h}$. The medium was removed, and fresh medium was added with MTS (final concentration on the well of $158.5 \mu \mathrm{g} / \mathrm{mL}$ ). Similarly, the cells were maintained at $37^{\circ} \mathrm{C}$ and $5 \% \mathrm{CO}_{2}$ for $1 \mathrm{~h}$, and the absorbance at $490 \mathrm{~nm}$ was measured. Three to six independent experiments were performed, each in quadruplicate. Results were expressed as percentage relative to control, which was considered as $100 \%$ cell viability.

\subsection{Immunoblotting Analysis}

A total of $30 \mu \mathrm{g}$ of total protein from each condition was resolved by SDS-PAGE in $12 \%$ polyacrylamide gels prepared as described by [73]. Gels were blotted onto PVDF membranes, which were incubated with primary antibody diluted in 5\% BSA (anti-CAPN1 diluted 1:500 (\#2556; Cell Signaling, Danvers, MA, USA), anti-TGFB diluted 1:100 (ab92486; Abcam, Cambridge, UK), anti-CCN3, anti-GDF15 and anti-MIF diluted 1:100 and antiCD9 diluted 1:200 (sc-136967, sc-377195, sc-271631, sc-13118 respectively; Santa Cruz Biotechnology, Heidelberg, Germany) overnight at $4{ }^{\circ} \mathrm{C}$, washed and incubated with 
horseradish peroxidase-conjugated anti-mouse (R\&D Systems, Minneapolis, MN, USA) or anti-rabbit (Jackson ImmunoResearch, Cambridgeshire, UK) antibodies for $2 \mathrm{~h}$ at RT. Immunoreactive bands were detected by enhanced chemiluminescence ECL (Millipore ${ }^{\circledR}$ ) according to the manufacturer's instructions, and images were recorded using a ChemiDoc XRS System (Bio-Rad Laboratories, Hercules, CA, USA). Protein loading control was performed with Ponceau S staining.

\subsection{In Vitro Scratch Assay}

Breast cancer cell migration was assessed under exposure to CM2D/CM3D $(10 \times$ concentrated) and/or Dox (100 nM) through an in vitro scratch assay, performed in accordance with [16,18]. Briefly, $2 \times 10^{5}$ MDA-MB-231 cells were seeded in 24-well plates in complete culture medium. After $24 \mathrm{~h}$, a scratch was performed using a $200 \mu \mathrm{L}$ sterile pipette tip, and cells were incubated in serum-free medium containing the test compounds. Scratches were evaluated microscopically (Motic AE 2000 inverted microscope, Barcelona, Spain), and three images of each scratch were recorded using a Moticam 2500 at defined time points: 0, 20 and 30 h. Cell migration was measured in Motic Images PLUS v2.0 software by calculating scratch closure, given as the total migrated area after treatments in relation to the initial scratch area at $0 \mathrm{~h}$ (considered as $0 \%$ wound closure).

\subsection{In Vitro Chemoinvasion Assay}

The chemotactic invasion of MDA-MB-231 cells was evaluated in a transwell assay as previously described [67]. The assay was performed in 24-well plates containing transwell inserts with transparent PET membranes of $8 \mu \mathrm{m}$ pores (Corning, Corning, NY, USA) overlaid with Matrigel (Corning) diluted in serum-free medium (1:30). Briefly, $1 \times 10^{5}$ cells were seeded in the upper chamber in serum-free medium, while complete culture medium (chemoattractant) was added to the lower chamber. The test compounds were added to both chambers, and cells were incubated for $24 \mathrm{~h}$ at $37^{\circ} \mathrm{C}$ in a $5 \% \mathrm{CO} 2$ in air atmosphere. Cells in the upper part of the insert were removed using a cotton swab, and the invading cells in the lower part of the inserts were fixed with $96 \%$ cold ethanol for $15 \mathrm{~min}$ at $4{ }^{\circ} \mathrm{C}$, stained with a $0.1 \%$ crystal violet solution for $10 \mathrm{~min}$ and then left to dry at $4{ }^{\circ} \mathrm{C}$. The amount of cell attached dye was dissolved with a $1 \%$ acid acetic in ethanol solution, and optic density was measured at $595 \mathrm{~nm}$ using a microplate spectrophotometer (SPECTROstar Omega, BMG LABTECH). Results were expressed as percentage relative to control.

\subsection{Statistical Analysis}

All statistical analyses of cell data were performed in GraphPad Prism software (La Jolla, CA, USA). Comparisons were analyzed by one-way and two-way ANOVA followed by Tukey's post hoc test. Results are expressed as mean \pm standard deviation (SD), and $p$-values are presented for statistically significant results $\left({ }^{*} p<0.05,{ }^{* *} p<0.01\right.$, *** $p<0.001$ and $\left.{ }^{* * * *} p<0.0001\right)$.

\section{Conclusions}

In this paper, we present an approach for using the secretome of MSCs in the perspective of adjuvant treatment to Dox chemotherapy for breast cancer. Remarkably, we demonstrated that the MSC secretome, mainly CM3D, was significantly effective in protecting non-tumorigenic mammary epithelial cells and cardiomyocytes from the cytotoxic effect of Dox at a clinically relevant concentration, while it did not affect breast cancer cells. Moreover, we showed that the protective role of MSC secretome on non-tumor cells was greater in the form of CM3D, along with less interference with Dox. We further proposed that the mechanism behind CM3D effects may be due to the presence of proteins involved in biological processes such as cytoprotection, namely by regulating cell proliferation (CAPN1, CST1, LAMC2, RANBP3), migration (MMP8, PDCD5) and invasion (TIMP1, TIMP2), oxidative stress (COX6B1, AIFM1, CD9, GSR) and inflammation (CCN3, ANXA5, 
CDH13, GDF15). This work contributed to the development of novel adjuvant anticancer therapies, envisioning safer and more efficient use of chemotherapeutic agents.

Author Contributions: J.P.M., N.G.O., V.M.C., F.R. and S.P.C.: conception and design. A.S.S., S.P.C., B.A., V.M.C., V.Y., F.R., M.C., N.G.O. and J.P.M.: wrote and critically review the manuscript. A.S.S., S.P.C., B.A., V.M.C., F.D., V.Y., R.V., N.G.O. and J.P.M.: collection and data analysis; A.S.S., S.P.C., B.A., V.M.C., F.D. and V.Y.: figure design and elaboration. J.P.M. and N.G.O.: directed manuscript. All authors have read and agreed to the published version of the manuscript.

Funding: This study was partially supported by FCT (PTDC/MED-TOX/29183/2017; SFRH/BHD/ 110001/2015 and DL57/2016/CP1334/CT0006 for VMC; and IF/00286/2015 for RV), by strategic funding for iMed.ULisboa (UIDB/04138/2020 and UIDP/04138/2020) and by European Union, Quadro de Referência Estratégico Nacional (QREN), Fundo Europeu de Desenvolvimento Regional (FEDER) and Programa Operacional Fatores de Competitividade (COMPETE) for UnIC (UID/IC/00051/2019), iBiMED (UID/BIM/04501/2020 and POCI-01-0145-FEDER-007628) and LAQV/REQUIMTE (UIDB/50006/2020).

Institutional Review Board Statement: The study was approved by the Ethics Committee of the Hospital Dr. José de Almeida (Cascais, Portugal), in the scope of a research protocol between ECBio (Research \& Development in Biotechnology, S.A., Amadora, Portugal) and HPP Saúde (Parcerias Cascais, S.A., Lisbon, Portugal).

Informed Consent Statement: Umbilical cord donations, with written informed consent, as well as umbilical cord procurement were carried out according to Directive 2004/23/EC of the European Parliament and of the Council of 31 March 2004 on setting standards of quality and safety for the donation, procurements, testing, processing, preservation, storage and distribution of human tissues and cells.

Data Availability Statement: The mass spectrometry proteomics data have been deposited in the ProteomeXchange Consortium via the PRIDE partner repository with the dataset identifier PXD029795.

Acknowledgments: VIB Proteomics Core, COST Actions (EU Framework Programme Horizon 2020) CA16113 and CA16119 are also acknowledged.

Conflicts of Interest: The authors declare no conflict of interest.

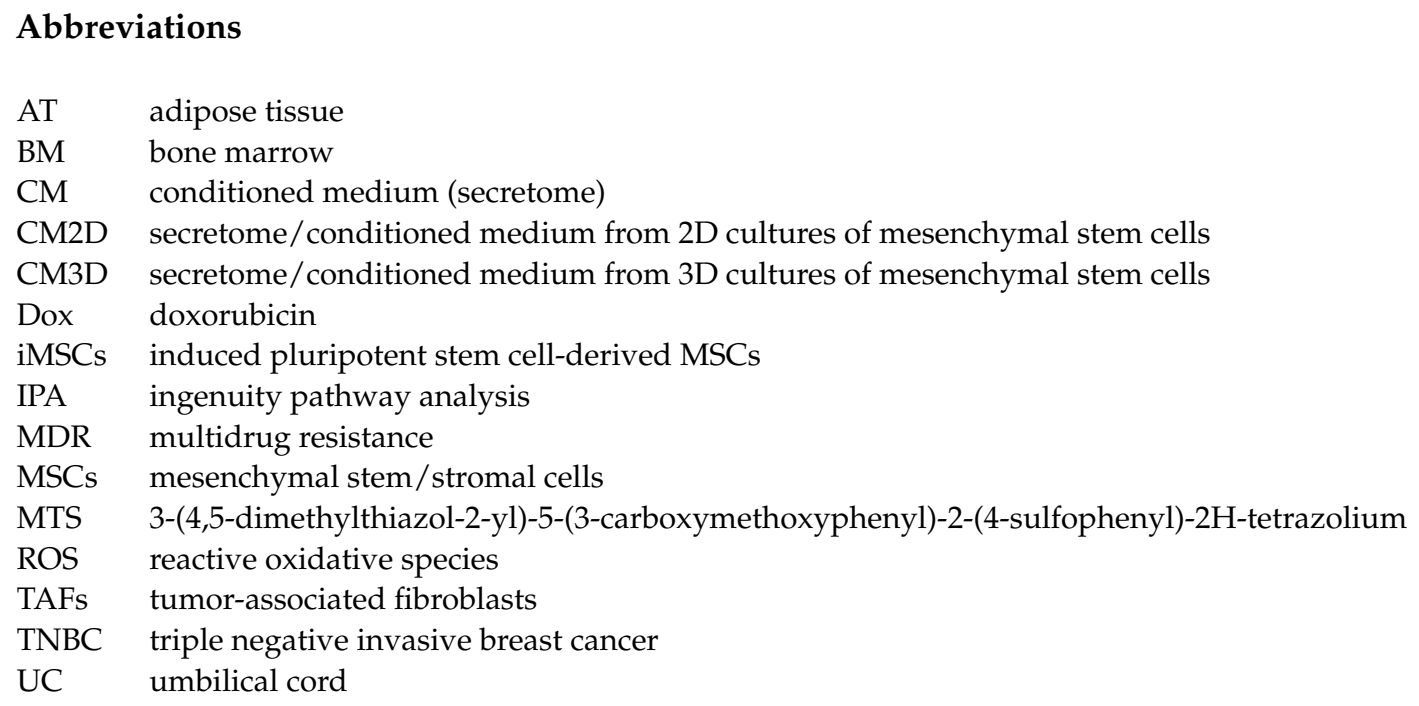

\section{References}

1. DeSantis, C.E.; Ma, J.; Gaudet, M.M.; Newman, L.A.; Miller, K.D.; Goding Sauer, A.; Jemal, A.; Siegel, R.L. Breast cancer statistics, 2019. CA Cancer J. Clin. 2019, 69, 438-451. [CrossRef] [PubMed]

2. Jones, S.E. Metastatic breast cancer: The treatment challenge. Clin. Breast Cancer 2008, 8, 224-233. [CrossRef]

3. Henriksen, P.A. Anthracycline cardiotoxicity: An update on mechanisms, monitoring and prevention. Heart 2018, 104, 971-977. [CrossRef] [PubMed] 
4. Tacar, O.; Sriamornsak, P.; Dass, C.R. Doxorubicin: An update on anticancer molecular action, toxicity and novel drug delivery systems. J. Pharm. Pharmacol. 2012, 65, 157-170. [CrossRef]

5. Marinello, J.; Delcuratolo, M.; Capranico, G. Anthracyclines as Topoisomerase II Poisons: From Early Studies to New Perspectives. Int. J. Mol. Sci. 2018, 19, 3480. [CrossRef]

6. Cai, F.; Luis, M.A.F.; Lin, X.; Wang, M.; Cai, L.; Cen, C.; Biskup, E. Anthracycline-induced cardiotoxicity in the chemotherapy treatment of breast cancer: Preventive strategies and treatment. Mol. Clin. Oncol. 2019, 11, 15-23. [CrossRef] [PubMed]

7. Reis-Mendes, A.F.; Sousa, E.; de Lourdes Bastos, M.; Marisa Costa, V. The Role of the Metabolism of Anticancer Drugs in Their Induced-Cardiotoxicity. Curr. Drug Metab. 2015, 17, 75-90. [CrossRef]

8. Whirl-Carrillo, M.; McDonagh, E.M.; Hebert, J.M.; Gong, L.; Sangkuhl, K.; Thorn, C.F.; Altman, R.B.; Klein, T.E. Pharmacogenomics Knowledge for Personalized Medicine. Clin. Pharmacol. Ther. 2012, 92, 414-417. [CrossRef]

9. Hrynchak, I.; Sousa, E.; Pinto, M.; Costa, V.M. The importance of drug metabolites synthesis: The case-study of cardiotoxic anticancer drugs. Drug Metab. Rev. 2017, 49, 158-196. [CrossRef]

10. Pugazhendhi, A.; Edison, T.N.J.I.; Velmurugan, B.K.; Jacob, J.A.; Karuppusamy, I. Toxicity of Doxorubicin (Dox) to different experimental organ systems. Life Sci. 2018, 200, 26-30. [CrossRef]

11. Abushouk, A.I.; Abdo Salem, A.M.; Saad, A.; Afifi, A.M.; Afify, A.Y.; Afify, H.; Salem, H.S.E.; Ghanem, E.; Abdel-Daim, M.M. Mesenchymal stem cell therapy for doxorubicin-induced cardiomyopathy: Potential mechanisms, governing factors, and implications of the heart stem cell debate. Front. Pharmacol. 2019, 10, 635. [CrossRef] [PubMed]

12. Sosa, V.; Moliné, T.; Somoza, R.; Paciucci, R.; Kondoh, H.; Leonart, M.E. Oxidative stress and cancer: An overview. Ageing Res. Rev. 2013, 12, 376-390. [CrossRef]

13. Wang, J.; Seebacher, N.; Shi, H.; Kan, Q.; Duan, Z. Novel strategies to prevent the development of multidrug resistance (MDR) in cancer. Oncotarget 2017, 8, 84559-84571. [CrossRef] [PubMed]

14. Liu, Y.; Li, Q.; Zhou, L.; Xie, N.; Nice, E.C.; Zhang, H.; Huang, C.; Lei, Y. Cancer drug resistance: Redox resetting renders a way. Oncotarget 2016, 7, 42740-42761. [CrossRef] [PubMed]

15. Santos, J.M.; Bárcia, R.N.; Simões, S.I.; Gaspar, M.M.; Calado, S.; Água-Doce, A.; Almeida, S.C.; Almeida, J.; Filipe, M.; Teixeira, M.; et al. The role of human umbilical cord tissue-derived mesenchymal stromal cells (UCX®) in the treatment of inflammatory arthritis. J. Transl. Med. 2013, 11, 18. [CrossRef] [PubMed]

16. Santos, J.M.; Camões, S.P.; Filipe, E.; Cipriano, M.; Barcia, R.N.; Filipe, M.; Teixeira, M.; Simões, S.; Gaspar, M.; Mosqueira, D.; et al. Three-dimensional spheroid cell culture of umbilical cord tissue-derived mesenchymal stromal cells leads to enhanced paracrine induction of wound healing. Stem Cell Res. Ther. 2015, 6, 90. [CrossRef] [PubMed]

17. Nascimento, D.S.; Mosqueira, D.; Sousa, L.M.; Teixeira, M.; Filipe, M.; Resende, T.P.; Araújo, A.F.; Valente, M.; Almeida, J.; Martins, J.P.; et al. Human umbilical cord tissue-derived mesenchymal stromal cells attenuate remodeling after myocardial infarction by proangiogenic, antiapoptotic, and endogenous cell-activation mechanisms. Stem Cell Res. Ther. 2014, 5, 5. [CrossRef] [PubMed]

18. Miranda, J.P.; Camões, S.P.; Gaspar, M.M.; Rodrigues, J.S.; Carvalheiro, M.; Bárcia, R.N.; Cruz, P.; Cruz, H.; Simões, S.; Santos, J.M. The secretome derived from 3D-cultured umbilical cord tissue MSCs counteracts manifestations typifying rheumatoid arthritis. Front. Immunol. 2019, 10, 18. [CrossRef]

19. Khan, M.; Adil, S.E.R.; Olson, A.L. The role of mesenchymal stem cells in oncology and regenerative medicine. Futur. Oncol. 2017, 13, 821-831. [CrossRef]

20. Karnoub, A.E.; Dash, A.B.; Vo, A.P.; Sullivan, A.; Brooks, M.W.; Bell, G.W.; Richardson, A.L.; Polyak, K.; Tubo, R.; Weinberg, R.A. Mesenchymal stem cells within tumour stroma promote breast cancer metastasis. Nature 2007, 449, 557-563. [CrossRef]

21. Xu, W.; Bian, Z.; Fan, Q.; Li, G.; Tang, T. Human mesenchymal stem cells (hMSCs) target osteosarcoma and promote its growth and pulmonary metastasis. Cancer Lett. 2009, 281, 32-41. [CrossRef]

22. Trivanović, D.; Krstić, J.; Jauković, A.; Bugarski, D.; Santibanez, J.F. Mesenchymal stromal cell engagement in cancer cell epithelial to mesenchymal transition. Dev. Dyn. 2018, 247, 359-367. [CrossRef]

23. Zhai, Y.; Wu, W.; Xi, X.; Yu, R. Adipose-Derived Stem Cells Promote Proliferation and Invasion in Cervical Cancer by Targeting the HGF/c-MET Pathway. Cancer Manag. Res. 2020, 12, 11823-11832. [CrossRef] [PubMed]

24. Li, F.; Chen, X.; Shang, C.; Ying, Q.; Zhou, X.; Zhu, R.; Lu, H.; Hao, X.; Dong, Q.; Jiang, Z. Bone Marrow Mesenchymal Stem Cells-Derived Extracellular Vesicles Promote Proliferation, Invasion and Migration of Osteosarcoma Cells via the lncRNA MALAT1/miR-143/NRSN2/Wnt/ $\beta$-Catenin Axis. OncoTargets Ther. 2021, 14, 737-749. [CrossRef] [PubMed]

25. Ayuzawa, R.; Doi, C.; Rachakatla, R.S.; Pyle, M.M.; Maurya, D.K.; Troyer, D.; Tamura, M. Naïve human umbilical cord matrix derived stem cells significantly attenuate growth of human breast cancer cells in vitro and in vivo. Cancer Lett. 2009, 280, 31-37. [CrossRef]

26. Fong, C.; Chak, L.; Biswas, A.; Tan, J.; Gauthaman, K. Human Wharton's Jelly Stem Cells Have Unique Transcriptome Profiles Compared to Human Embryonic Stem Cells and Other Mesenchymal Stem Cells. Stem Cell Rev. Rep. 2011, 7, 1-16. [CrossRef] [PubMed]

27. Gauthaman, K.; Yee, F.C.; Cheyyatraivendran, S.; Biswas, A.; Choolani, M.; Bongso, A. Human umbilical cord wharton's jelly stem cell (hWJSC) extracts inhibit cancer cell growth in vitro. J. Cell. Biochem. 2012, 113, 2027-2039. [CrossRef] 
28. Akimoto, K.; Kimura, K.; Nagano, M.; Takano, S.; To'a Salazar, G.; Yamashita, T.; Ohneda, O. Umbilical Cord Blood-Derived Mesenchymal Stem Cells Inhibit, But Adipose Tissue-Derived Mesenchymal Stem Cells Promote, Glioblastoma Multiforme Proliferation. Stem Cells Dev. 2013, 22, 1370-1386. [CrossRef]

29. Clarke, M.R.; Imhoff, F.M.; Baird, S.K. Mesenchymal stem cells inhibit breast cancer cell migration and invasion through secretion of tissue inhibitor of metalloproteinase-1 and -2. Mol. Carcinog. 2015, 54, 1214-1219. [CrossRef]

30. Yuan, Y.; Zhou, C.; Chen, X.; Tao, C.; Cheng, H.; Lu, X. Suppression of tumor cell proliferation and migration by human umbilical cord mesenchymal stem cells: A possible role for apoptosis and Wnt signaling. Oncol. Lett. 2018, 15, 8536-8544. [CrossRef]

31. Mirabdollahi, M.; Sadeghi-Aliabadi, H.; Javanmard, S.H. Human Wharton's jelly mesenchymal stem cells-derived secretome could inhibit breast cancer growth in vitro and in vivo. Iran. J. Basic Med. Sci. 2020, 23, 945-953. [CrossRef] [PubMed]

32. Subramanian, A.; Gan, S.U.; Ngo, K.S.; Gauthaman, K.; Biswas, A.; Choolani, M.; Bongso, A.; Fong, C.Y. Human umbilical cord Wharton's jelly mesenchymal stem cells do not transform to tumor-associated fibroblasts in the presence of breast and ovarian cancer cells unlike bone marrow mesenchymal stem cells. J. Cell. Biochem. 2012, 113, 1886-1895. [CrossRef] [PubMed]

33. Regmi, S.; Jeong, J.-H. Superiority of three-dimensional stem cell clusters over monolayer culture: An archetype to biological application. Macromol. Res. 2016, 24, 1037-1046. [CrossRef]

34. Davidson, M.; Nesti, C.; Palenzuela, L.; Walker, W.; Hernandez, E.; Protas, L.; Hirano, M.; Isaac, N. Novel cell lines derived from adult human ventricular cardiomyocytes. J. Mol. Cell. Cardiol. 2005, 39, 133-147. [CrossRef]

35. Zhang, Y.; Liang, X.; Liao, S.; Wang, W.; Wang, J.; Li, X.; Ding, Y.; Liang, Y.; Gao, F.; Yang, M.; et al. Potent Paracrine Effects of human induced Pluripotent Stem Cell-derived Mesenchymal Stem Cells Attenuate Doxorubicin-induced Cardiomyopathy. Sci. Rep. 2015, 5, 11235. [CrossRef]

36. Hendijani, F.; Javanmard, S.H.; Rafiee, L.; Sadeghi-Aliabadi, H. Effect of human Wharton's jelly mesenchymal stem cell secretome on proliferation, apoptosis and drug resistance of lung cancer cells. Res. Pharm. Sci. 2015, 10, 134-142. [PubMed]

37. Scotland, P.B.; Heath, J.L.; Conway, A.E.; Porter, N.B.; Armstrong, M.B.; Walker, J.A.; Klebig, M.L.; Lavau, C.P.; Wechsler, D.S. The PICALM Protein Plays a Key Role in Iron Homeostasis and Cell Proliferation. PLoS ONE 2012, 7, e44252. [CrossRef]

38. McDonald, P.C.; Fielding, A.B.; Dedhar, S. Integrin-linked kinase-Essential roles in physiology and cancer biology. J. Cell Sci. 2008, 121, 3121-3132. [CrossRef]

39. Conroy, H.; Mawhinney, L.; Donnelly, S.C. Inflammation and cancer: Macrophage migration inhibitory factor (MIF)-the potential missing link. QJM 2010, 103, 831-836. [CrossRef]

40. Li, W.; Liang, J.; Zhang, Z.; Lou, H.; Zhao, L.; Xu, Y.; Ou, R. MicroRNA-329-3p targets MAPK1 to suppress cell proliferation, migration and invasion in cervical cancer. Oncol. Rep. 2017, 37, 2743-2750. [CrossRef]

41. Liu, R.-M.; Sun, D.-N.; Jiao, Y.-L.; Wang, P.; Zhang, J.; Wang, M.; Ma, J.; Sun, M.; Gu, B.-L.; Chen, P.; et al. Macrophage migration inhibitory factor promotes tumor aggressiveness of esophageal squamous cell carcinoma via activation of Akt and inactivation of GSK3ß. Cancer Lett. 2018, 412, 289-296. [CrossRef]

42. Fan, C.; Tu, C.; Qi, P.; Guo, C.; Xiang, B.; Zhou, M.; Li, X.; Wu, X.; Li, X.; Li, G.; et al. GPC6 promotes cell proliferation, migration, and invasion in nasopharyngeal carcinoma. J. Cancer 2019, 10, 3926-3932. [CrossRef] [PubMed]

43. Dai, F.; Lin, X.; Chang, C.; Feng, X.H. Nuclear Export of Smad2 and Smad3 by RanBP3 Facilitates Termination of TGF- $\beta$ Signaling. Dev. Cell 2009, 16, 345-357. [CrossRef] [PubMed]

44. Nian, H.; Ma, B. Calpain-calpastatin system and cancer progression. Biol. Rev. 2021, 96, 961-975. [CrossRef] [PubMed]

45. Kinoshita, T.; Nohata, N.; Hanazawa, T.; Kikkawa, N.; Yamamoto, N.; Yoshino, H.; Itesako, T.; Enokida, H.; Nakagawa, M.; Okamoto, Y.; et al. Tumour-suppressive microRNA-29s inhibit cancer cell migration and invasion by targeting laminin-integrin signalling in head and neck squamous cell carcinoma. Br. J. Cancer 2013, 109, 2636-2645. [CrossRef] [PubMed]

46. Liu, Y.; Ma, H.; Wang, Y.; Du, X.; Yao, J. Cystatin SN affects cell proliferation by regulating the ER $\alpha / \mathrm{PI} 3 \mathrm{~K} / \mathrm{AKT} / \mathrm{ER} \alpha$ loopback pathway in breast cancer. OncoTargets Ther. 2019, 12, 11359-11369. [CrossRef]

47. Nitulescu, G.; Van De Venter, M.; Nitulescu, G.; Ungurianu, A.; Juzenas, P.; Peng, Q.; Olaru, O.; Grădinaru, D.; Tsatsakis, A.; Tsoukalas, D.; et al. The Akt pathway in oncology therapy and beyond (Review). Int. J. Oncol. 2018, 53, 2319-2331. [CrossRef]

48. Modjtahedi, N.; Giordanetto, F.; Madeo, F.; Kroemer, G. Apoptosis-inducing factor: Vital and lethal. Trends Cell Biol. 2006, 16, 264-272. [CrossRef]

49. Lüersen, K.; Stegehake, D.; Daniel, J.; Drescher, M.; Ajonina, I.; Ajonina, C.; Hertel, P.; Woltersdorf, C.; Liebau, E. The Glutathione Reductase GSR-1 Determines Stress Tolerance and Longevity in Caenorhabditis elegans. PLoS ONE 2013, 8, e60731. [CrossRef]

50. Cole, S.P.C. Targeting multidrug resistance protein 1 (MRP1, ABCC1): Past, present, and future. Annu. Rev. Pharmacol. Toxicol. 2014, 54, 95-117. [CrossRef]

51. Joshi, M.B.; Philippova, M.; Ivanov, D.; Allenspach, R.; Erne, P.; Resink, T.J. T-cadherin protects endothelial cells from oxidative stress-induced apoptosis. FASEB J. 2005, 19, 1737-1739. [CrossRef] [PubMed]

52. Williams, A.S.; Kasahara, D.I.; Verbout, N.G.; Fedulov, A.V.; Zhu, M.; Si, H.; Wurmbrand, A.P.; Hug, C.; Ranscht, B.; Shore, S.A. Role of the Adiponectin binding protein, T-cadherin (Cdh13), in allergic airways responses in mice. PLoS ONE 2012, 7, e41088. [CrossRef] [PubMed]

53. Lee, E.J.; Kim, H.S. The anti-inflammatory role of tissue inhibitor of metalloproteinase-2 in lipopolysaccharide-stimulated microglia. J. Neuroinflamm. 2014, 11, 116. [CrossRef]

54. Zhang, L.; Qin, Z.; Li, R.; Wang, S.; Wang, W.; Tang, M.; Zhang, W. The role of ANXA5 in DBP-induced oxidative stress through ERK/Nrf2 pathway. Environ. Toxicol. Pharmacol. 2019, 72, 103236. [CrossRef] [PubMed] 
55. Casals, G.; Fernández-Varo, G.; Melgar-Lesmes, P.; Marfà, S.; Reichenbach, V.; Morales-Ruiz, M.; Jiménez, W. Factors Involved in Extracellular Matrix Turnover in Human Derived Cardiomyocytes. Cell. Physiol. Biochem. 2013, 32, 1125-1136. [CrossRef] [PubMed]

56. Abd El Kader, T.; Kubota, S.; Janune, D.; Nishida, T.; Hattori, T.; Aoyama, E.; Perbal, B.; Kuboki, T.; Takigawa, M. Anti-fibrotic effect of CCN3 accompanied by altered gene expression profile of the CCN family. J. Cell Commun. Signal. 2013, 7, 11-18. [CrossRef]

57. Huang, X.; Ni, B.; Mao, Z.; Xi, Y.; Chu, X.; Zhang, R.; Ma, X.; You, H. NOV/CCN3 induces cartilage protection by inhibiting PI3K/AKT/mTOR pathway. J. Cell. Mol. Med. 2019, 23, 7525-7534. [CrossRef]

58. Zhang, W.; Wang, Y.; Wan, J.; Zhang, P.; Pei, F. COX6B1 relieves hypoxia/reoxygenation injury of neonatal rat cardiomyocytes by regulating mitochondrial function. Biotechnol. Lett. 2019, 41, 59-68. [CrossRef]

59. Mofid, A.; Newman, N.S.; Paul, P.J.; Abbasi, C.; Matkar, P.N.; Rudenko, D.; Kuliszewski, M.A.; Chen, H.H.; Afrasiabi, K.; Tsoporis, J.N.; et al. Cardiac overexpression of S100A6 attenuates cardiomyocyte apoptosis and reduces infarct size after myocardial ischemia-reperfusion. J. Am. Heart Assoc. 2017, 6, e004738. [CrossRef]

60. Echtermeyer, F.; Harendza, T.; Hubrich, S.; Lorenz, A.; Herzog, C.; Mueller, M.; Schmitz, M.; Grund, A.; Larmann, J.; Stypmann, J.; et al. Syndecan-4 signalling inhibits apoptosis and controls NFAT activity during myocardial damage and remodelling. Cardiovasc. Res. 2011, 92, 123-131. [CrossRef]

61. De Luca, A.; Lamura, L.; Gallo, M.; Maffia, V.; Normanno, N. Mesenchymal stem cell-derived interleukin-6 and vascular endothelial growth factor promote breast cancer cell migration. J. Cell Biochem. 2012, 113, 3363-3370. [CrossRef]

62. Chen, L.L.; Gao, G.X.; Shen, F.X.; Chen, X.; Gong, X.H.; Wu, W.J. SDC4 gene silencing favors human papillary thyroid carcinoma cell apoptosis and inhibits epithelial mesenchymal transition via wnt/ $\beta$-catenin pathway. Mol. Cells 2018, 41, 853-867. [CrossRef]

63. Dobson, J.R.; Taipaleenmäki, H.; Hu, Y.J.; Hong, D.; van Wijnen, A.J.; Stein, J.L.; Stein, G.S.; Lian, J.B.; Pratap, J. Hsa-mir-30c promotes the invasive phenotype of metastatic breast cancer cells by targeting NOV/CCN3. Cancer Cell Int. 2014, 14, 73. [CrossRef] [PubMed]

64. Juurikka, K.; Butler, G.S.; Salo, T.; Nyberg, P.; Åström, P. The role of MMP8 in cancer: A systematic review. Int. J. Mol. Sci. 2019, 20, 4506. [CrossRef] [PubMed]

65. Zhao, H.; Peng, C.; Lu, X.; Guo, M.; Yang, T.; Zhou, J.; Hai, Y. PDCD5 inhibits osteosarcoma cell metastasis via targeting tgf- $\beta 1 /$ smad signaling pathway and is associated with good prognosis. Am. J. Transl. Res. 2019, 11, 1116-1128.

66. Menyhárt, O.; Harami-Papp, H.; Sukumar, S.; Schäfer, R.; Magnani, L.; de Barrios, O.; Győrffy, B. Guidelines for the selection of functional assays to evaluate the hallmarks of cancer. Biochim. Biophys. Acta-Rev. Cancer 2016, 1866, 300-319. [CrossRef] [PubMed]

67. Fernandes, A.S.; Flórido, A.; Saraiva, N.; Cerqueira, S.; Ramalhete, S.; Cipriano, M.; Cabral, M.F.; Miranda, J.P.; Castro, M.; Costa, J.; et al. Role of the Copper(II) Complex Cu[15]pyN5 in Intracellular ROS and Breast Cancer Cell Motility and Invasion. Chem. Biol. Drug Des. 2015, 86, 578-588. [CrossRef] [PubMed]

68. Santos, J.M.; Soares, R.; Coelho, M.; Martins, J.P.; Basto, V.; Cruz, P.; Cruz, H. Optimised and Defined Method for Isolation and Preservation of Percursor Cells from Human Umbilical Cord. 2009. INPI PAT20081000083882; PCT/IB2008/054067; WO200904. Available online: https:/ / patentscope.wipo.int/search/en/detail.jsf?docId=WO2009044379 (accessed on 8 March 2021).

69. Martins, J.P.; Santos, J.M.; Almeida, J.M.; Filipe, M.A.; de Almeida, M.V.T.; Almeida, S.C.P.; Água-Doce, A.; Varela, A.; Gilljam, M.; Stellan, B.; et al. Towards an advanced therapy medicinal product based on mesenchymal stromal cells isolated from the umbilical cord tissue: Quality and safety data. Stem Cell Res. Ther. 2014, 5, 9. [CrossRef]

70. Perez-Riverol, Y.; Csordas, A.; Bai, J.; Bernal-Llinares, M.; Hewapathirana, S.; Kundu, D.J.; Inuganti, A.; Griss, J.; Mayer, G.; Eisenacher, M.; et al. The PRIDE database and related tools and resources in 2019: Improving support for quantification data. Nucleic Acids Res. 2019, 47, D442-D450. [CrossRef]

71. Kuleshov, M.V.; Jones, M.R.; Rouillard, A.D.; Fernandez, N.F.; Duan, Q.; Wang, Z.; Koplev, S.; Jenkins, S.L.; Jagodnik, K.M.; Lachmann, A.; et al. Enrichr: A comprehensive gene set enrichment analysis web server 2016 update. Nucleic Acids Res. 2016, 44, W90-W97. [CrossRef]

72. Szklarczyk, D.; Gable, A.L.; Lyon, D.; Junge, A.; Wyder, S.; Huerta-Cepas, J.; Simonovic, M.; Doncheva, N.T.; Morris, J.H.; Bork, P.; et al. STRING v11: Protein-protein association networks with increased coverage, supporting functional discovery in genome-wide experimental datasets. Nucleic Acids Res. 2019, 47, D607-D613. [CrossRef] [PubMed]

73. Miranda, J.; Bakheit, M.A.; Liu, Z.; Yin, H.; Mu, Y.; Guo, S.; Beyer, D.; Oliva, A.; Ahmed, J.S.; Seitzer, U. Development of a recombinant indirect ELISA for the diagnosis of Theileria sp. (China) infection in small ruminants. Parasitol. Res. 2006, 98, 561-567. [CrossRef] [PubMed] 